\title{
TAPHONOMY AND PALEOECOLOGY OF SAN JOSECITO CAVE, NUEVO LEON, MEXICO
}

\author{
ARROYO-CABRALES, Joaquín, Subdirección de Laboratorios y Apoyo \\ Académico, I.N.A.H., Moneda \# 16, Col. Centro, 06060 México, D. F., México; \\ JOHNSON, Eileen, Museum of Texas Tech University, Box 43191, Lubbock, \\ Texas 79409, U.S.A.
}

The hypothesis to test in this study was that the paleoenvironment at the mid-Wisconsinan (40,000 to 25,000 years BP) could bear a forest similar to a Rocky Mountain Forest, allowing the presence of similar faunal elements.

To test this hypothesis, it was decided to reexamine the available evidence from San Josecito Cave (northeastern México), one of the most important paleontological sites for the late Pleistocene of North America. Most of its importance was based on the high number of taxa represented (at least 128 species, including 65 mammal ones). However, the locality was potentially important in developing a regional paleoenvironmental model. Renewed, stratigraphically-controlled excavations allowed an insight into the taphonomic history and provided data to initiate a paleoenvironmental reconstruction.

Taphonomic analyses were undertaken, including quantification, breakage patterns, and spatial distribution. The different quantification methods provided comparable results if relative values were utilized. Breakage patterns appeared to point to the presence of avian predators as major agents in bone accumulation in stratum 720 .

Faunal comparisons show a great similarity between San Josecito Cave stratum 720 local fauna and the fauna from U-Bar Cave in southwestern New Mexico, U.S.A. Similarly, the stratum 720 local cave fauna appears to be composed of faunal elements predominantly occupying the Rocky Mountain Forests. Presently, this biome is found in the region where the cave is located. However, four specific associations within the Rocky Mountain Forests occur, and those cannot be identified with the ecological data available for recent and past taxa.

The significance of the new San Josecito Cave local fauna data is to provide the first inference on paleoclimate at the Mid-Wisconsin of northeastern México. It appears that the paleoclimate regime at about 28,000 years BP supported the same kind of vegetational association that presently occurs in the cave region. It was probably similar to the present one with a continental climatic regime. Such a paleoclimate supported an harmonious fauna. With the onset of the Glacial Maximum at about 18,000 years BP, disharmonious communities apparently appeared with elements from tropical climates. 